\section{Photosubstitution of Pentaamminechlororuthenium(III) Hexacyanoruthenate(II) following Outer-Sphere Intervalence Excitation}

\author{
Arnd Vogler* and Josef Kisslinger \\ Universität Regensburg, Institut für Anorganische Chemie \\ D-8400 Regensburg, Federal Republic of Germany
}

Received November 13,1981

The chemistry of mixed-valence coordination compounds has been investigated extensively during the last 10 years. ${ }^{1,2}$ Starting with the preparation of the Creutz-Taube ion, ${ }^{3}$ much attention has been paid to binuclear complexes containing ruthenium in the formal oxidation states II and III. ${ }^{1,2}$ Electron transfer from Ru(II) to $\mathrm{Ru}$ (III) can occur thermally or optically by light absorption into intervalence-transfer (IT) bands. However, this photoredox process is apparently not associated with any permanent chemical change. A rapid back electron transfer seems to restore the starting complexes. ${ }^{4}$ On the contrary, photoredox reactions following inner- and outer-sphere IT excitation from $\mathrm{Fe}$ (II) and $\mathrm{Ru}(\mathrm{II})$ to $\mathrm{Co}$ (III) are well known. ${ }^{5,6}$ We report here our observation of a photochemical reaction induced by an optical $\mathrm{Ru}(\mathrm{II})$ to $\mathrm{Ru}(\mathrm{III})$ IT transition.

Upon mixture of aqueous $\left[\mathrm{Ru}^{\mathrm{III}}\left(\mathrm{NH}_{3}\right)_{5} \mathrm{Cl}\right] \mathrm{Cl}_{2}$ (slightly yellow ${ }^{7}$ ) and $\mathrm{K}_{4}\left[\mathrm{Ru}^{\mathrm{II}}(\mathrm{CN})_{6}\right]$ (colorless ${ }^{9}$ ) the solution turned reddish immediately. This red color is caused by a new absorption band with a maximum at $510 \mathrm{~nm}$ (Figure 1). At fairly high equimolar concentration of both ions $\left(>2.5 \times 10^{-3} \mathrm{M}\right)$ this band follows the Lambert-Beer law with $\epsilon=20$ at the $510-\mathrm{nm}$ maximum. It is assumed that ion pairing was complete. The new absorption band is assigned to an outer-sphere $\mathrm{Ru}$ (II) to $\mathrm{Ru}$ (III) IT transition within the ion pair $\left[\mathrm{Ru}\left(\mathrm{NH}_{3}\right)_{5} \mathrm{Cl}\right]^{2+} /\left[\mathrm{Ru}(\mathrm{CN})_{6}\right]^{4-}$. The deviation from the Lambert-Beer law at much lower concentrations $(<1.5$ $\left.\times 10^{-4} \mathrm{M}\right)$ was used to estimate the ion-pairing constant $\left(\kappa_{\mathrm{IP}}=\right.$ 216).

Upon irradiation of the IT band $\left(\lambda_{\text {irr }}>490 \mathrm{~nm}\right)$ the solution turned blue due to the formation of the complex [ $\left(\mathrm{NH}_{3}\right)_{5} \mathrm{Ru}^{\mathrm{III}}$ (NC) Ru(II)(CN) $\left.]_{5}\right]^{-10,11}$ (Figure 1). The blue color is caused by an IT absorption of this binuclear ion at $\lambda_{\max }=680 \mathrm{~nm}^{12}(\epsilon=$ 2800). The ion pair $\left[\mathrm{Ru}\left(\mathrm{NH}_{3}\right)_{5} \mathrm{Cl}\right]^{2+} /\left[\mathrm{Ru}(\mathrm{CN})_{6}\right]^{4-}$ underwent photoconversion to the binuclear complex with the quantum yield $\phi=0.002\left(\lambda_{\text {irr }}=546 \mathrm{~nm}\right)$.

The IT assignment of the visible absorption band of the ion pair $\left[\mathrm{Ru}\left(\mathrm{NH}_{3}\right)_{5} \mathrm{Cl}\right]^{2+} /\left[\mathrm{Ru}(\mathrm{CN})_{6}\right]^{4-}$ is based on the following considerations. The half-width of the $510-\mathrm{nm}$ band $\left(\Delta_{\text {obed }}=6582 \mathrm{~cm}^{-1}\right)$ is in excellent agreement with that calculated according to Hush ${ }^{14}$ $\left(\Delta_{\text {calod }}=6730 \mathrm{~cm}^{-1}\right)$. The energy of this IT band is higher than that of any other $\mathrm{Ru}(\mathrm{II}) / \mathrm{Ru}$ (III) system. ${ }^{1,2}$ This is certainly due to the relatively large stability of $\left[\mathrm{Ru}\left(\mathrm{NH}_{3}\right)_{5} \mathrm{Cl}\right]^{2+}$ toward reduction $\left(E_{0}=-0.04 \mathrm{~V}\right)^{15}$ and $\left[\mathrm{Ru}(\mathrm{CN})_{6}\right]^{4-}$ toward oxidation $\left(E_{0}\right.$

(1) Taube, H. Ann. N.Y. Acad. Sci. 1978, 313, 481 and references cited therein.

(2) Meyer, T. J. Acc. Chem. Res. 1978, 11, 94 and references cited therein.

(3) Creutz, C.; Taube, H. J. Am. Chem. Soc. 1969, 91, 3988

(4) Creutz, C.; Kroger, P.; Matsubara, T.; Netzel, T. L.; Sutin, N. J. Am Chem. Soc. 1979, 101, 5442

(5) Vogler, A.; Kunkely, H. Ber. Bunsenges. Phys. Chem. 1975, 79, 83, 301.

(6) Vogler, A.; Kisslinger, J. Angew. Chem., Int. Ed. Engl. 1982, 21, 77 (7) The longest wavelength absorption maximum of $\left[\mathrm{Ru}\left(\mathrm{NH}_{3}\right)_{5} \mathrm{Cl}\right]^{2+}$ appears at $328 \mathrm{~nm}, \epsilon=19300^{8}$

(8) Hartmans, H.; Buschbeck, C. Z. Phys. Chem. (Frankfurt/Main) 1957, 11,120 .

(9) $\left[\mathrm{Ru}(\mathrm{CN})_{6}\right]^{4-}$ does not absorb above $300 \mathrm{~nm} .^{5}$

(10) This reaction proceeds not only photochemically but also thermally. At $20^{\circ} \mathrm{C}$ the half-life of the ion pair was $7 \times 10^{4} \mathrm{~s}$ in aqueous solution.

(11) $\mathrm{Na}\left[\left(\mathrm{NH}_{3}\right)_{5} \mathrm{Ru}(\mathrm{NC}) \mathrm{Ru}(\mathrm{CN})_{5}\right] \cdot 3 \mathrm{H}_{2} \mathrm{O}$ was prepared by heating (60 $\left.{ }^{\circ} \mathrm{C}\right)$ an aqueous solution of $\left[\mathrm{Ru}\left(\mathrm{NH}_{3}\right)_{5} \mathrm{Cl}\right] \mathrm{Cl}_{2}$ and $\mathrm{K}_{4}\left[\mathrm{Ru}(\mathrm{CN})_{6}\right]$ for $2 \mathrm{~h}$. The crude product was precipitated with methanol, dissolved in water, and purified by passing the solution through a cation $\left(\mathrm{Na}^{+}\right)$exchange column.

(12) Ludi reported $\lambda_{\max }=675 \mathrm{~nm}^{13}$

(13) Ludi, A. Chimia 1972, 26, 647.

(14) Hush, N. S. Progr. Inorg. Chem. 1967, 8, 391

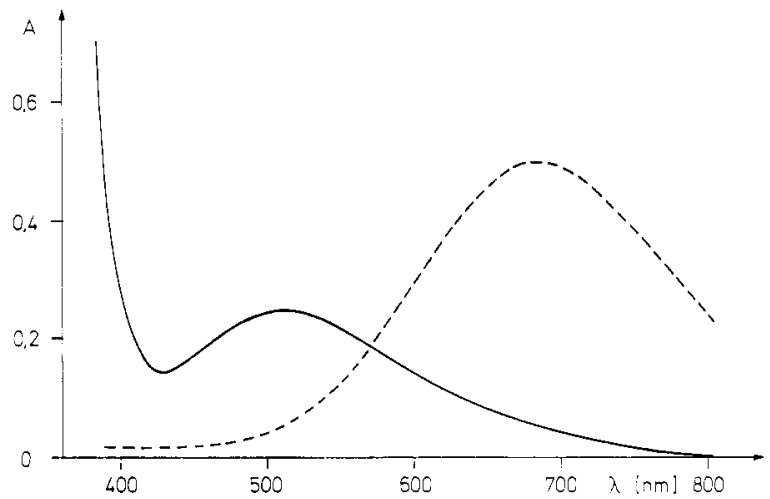

Figure 1. Electronic absorption spectra of aqueous solutions of equimolar $\left(1.25 \times 10^{-2} \mathrm{M}\right)\left[\mathrm{Ru}\left(\mathrm{NH}_{3}\right)_{5} \mathrm{Cl}\right] \mathrm{Cl}_{2}$ and $\mathrm{K}_{4}\left[\mathrm{Ru}(\mathrm{CN})_{6}\right](-)$ and $1.77 \times$ $10^{-4} \mathrm{M} \mathrm{Na}\left[\left(\mathrm{NH}_{3}\right)_{5} \mathrm{Ru}(\mathrm{NC}) \mathrm{Ru}(\mathrm{CN})_{5}\right] \cdot 3 \mathrm{H}_{2} \mathrm{O}(-\ldots)(298 \mathrm{~K}, 1-\mathrm{cm}$ cell $)$.

$=+0.86 \mathrm{~V}) .^{16}$ Within the ion pair the activation energy of thermal electron transfer, $E_{\mathrm{a}}=22 \mathrm{kcal} / \mathrm{mol}$, was calculated according to the equation $E_{\mathrm{a}}=0.25 E_{\mathrm{IT}}^{2}\left(E_{\mathrm{IT}}-\Delta E\right)^{-1}, 1,2$ where $E_{\mathrm{IT}}$ $=19609 \mathrm{~cm}^{-1}$ is the energy of the IT band maximum and $\Delta E$ is the energy difference between $\left[\mathrm{Ru}^{\mathrm{III}}\left(\mathrm{NH}_{3}\right)_{5} \mathrm{Cl}\right]^{2+} /\left[\mathrm{Ru}^{\mathrm{II}}(\mathrm{CN})_{6}\right]^{4-}$ and $\left[\mathrm{Ru}^{\mathrm{II}}\left(\mathrm{NH}_{3}\right)_{5} \mathrm{Cl}\right]^{+} /\left[\mathrm{R}^{\mathrm{III}}(\mathrm{CN})_{6}\right]^{3-}$ in vibrationally equilibrated states. $\Delta E=0.90 \mathrm{~V}$ was obtained from the standard potentials of these redox couples (see above).

It is suggested that photochemical product formation, following IT excitation of the ion pair, can be described by the reaction scheme given by eq $1-5$. The starting ion pair is substutitionally

$$
\begin{aligned}
& {\left[\mathrm{Ru}^{\mathrm{III}}\left(\mathrm{NH}_{3}\right)_{5} \mathrm{Cl}\right]^{2+} /\left[\mathrm{Ru}^{\mathrm{II}}(\mathrm{CN})_{6}\right]^{4-} \stackrel{h \nu}{\longrightarrow}} \\
& {\left[\mathrm{Ru}^{\mathrm{II}}\left(\mathrm{NH}_{3}\right)_{5} \mathrm{Cl}\right]^{+} /\left[\mathrm{Ru}^{\mathrm{III}}(\mathrm{CN})_{6}\right]^{3-}} \\
& {\left[\mathrm{Ru}^{\mathrm{II}}\left(\mathrm{NH}_{3}\right)_{5} \mathrm{Cl}\right]^{+} /\left[\mathrm{Ru}^{\mathrm{III}}(\mathrm{CN})_{6}\right]^{3-} \rightarrow} \\
& {\left[\mathrm{Ru}^{\mathrm{II}}\left(\mathrm{NH}_{3}\right)_{5} \mathrm{Cl}\right]^{+}+\left[\mathrm{Ru}^{\mathrm{III}}(\mathrm{CN})_{6}\right]^{3-}} \\
& {\left[\mathrm{Ru}^{\mathrm{II}}\left(\mathrm{NH}_{3}\right)_{5} \mathrm{Cl}\right]^{+}+\mathrm{H}_{2} \mathrm{O} \rightarrow\left[\mathrm{Ru}^{\mathrm{II}}\left(\mathrm{NH}_{3}\right)_{5} \mathrm{H}_{2} \mathrm{O}\right]^{2+}+\mathrm{Cl}^{-}} \\
& {\left[\mathrm{Ru}^{\mathrm{II}}\left(\mathrm{NH}_{3}\right)_{5} \mathrm{H}_{2} \mathrm{O}\right]^{2+}+\left[\mathrm{Ru}^{\mathrm{II}}(\mathrm{CN})_{6}\right]^{4-} \rightarrow} \\
& {\left[\left(\mathrm{NH}_{3}\right)_{5} \mathrm{Ru}^{\mathrm{II}}(\mathrm{NC}) \mathrm{Ru}^{\mathrm{II}}(\mathrm{CN})_{5}\right]^{2-}} \\
& {\left[\left(\mathrm{NH}_{3}\right)_{5} \mathrm{Ru}^{\mathrm{II}}(\mathrm{NC}) \mathrm{Ru}^{\mathrm{II}}(\mathrm{CN})_{5}\right]^{2-}+\left[\mathrm{Ru}^{\mathrm{III}}(\mathrm{CN})_{6}\right]^{3-} \rightarrow} \\
& {\left[\left(\mathrm{NH}_{3}\right)_{5} \mathrm{Ru}^{\mathrm{III}}(\mathrm{NC}) \mathrm{Ru}^{\mathrm{II}}(\mathrm{CN})_{5}\right]^{-}+\left[\mathrm{Ru}^{\mathrm{II}}(\mathrm{CN})_{6}\right]^{4-}}
\end{aligned}
$$

inert. $\left[\mathrm{Ru}(\mathrm{CN})_{6}\right]^{4-}$ is kinetically stable and also $\left[\mathrm{Ru}\left(\mathrm{NH}_{3}\right)_{5} \mathrm{Cl}\right]^{2+}$ is known to undergo only a very slow aquation of $\mathrm{Cl}^{-}$with a half-life greater than $10^{5} \mathrm{s.}^{17}$ The ion pair, generated by IT excitation (eq 1), may diffuse apart (eq 2). $\left[\mathrm{Ru}^{\mathrm{II}}\left(\mathrm{NH}_{3}\right)_{5} \mathrm{Cl}\right]^{+}$ aquates rapidly (eq 3 ) with $k=5 \mathrm{~s}^{-1} .18$ Substitutionally labile $\left[\mathrm{Ru}^{\mathrm{II}}\left(\mathrm{NH}_{3}\right)_{5} \mathrm{H}_{2} \mathrm{O}\right]^{2+19}$ reacts with $\left[\mathrm{Ru}^{\mathrm{II}}(\mathrm{CN})_{6}\right]^{4-}$ (eq 4), which is present in large excess. The formation of the binuclear complex is certainly facilitated by the high opposite charges of the reacting ions. Finally, electron transfer (eq 5) restores ruthenium to its stable oxidation states, yielding the blue product. The low quantum yield of the overall reaction $(\Phi=0.002)$ is most likely determined by the extremely rapid thermal reversal ${ }^{4}$ of reaction 1 , which competes with the diffusion apart from the primary electron-transfer products (eq 2). We tried to detect $\left[\mathrm{Ru}(\mathrm{CN})_{6}\right]^{3-}$ by flash photolysis using its absorption maximum at $455 \mathrm{~nm}(\epsilon$ $=875)^{20}$ to monitor its decay. A transient absorption of [Ru$\left.(\mathrm{CN})_{6}\right]^{3-}$ was not observed. According to the time resolution of our equipment in this experiment, the thermal reversal of reaction 1 should proceed with $k>10^{5} \mathrm{~s}^{-1}$.

(15) Lim, H. S.; Barclay, D. J.; Anson, F. C. Inorg. Chem. 1972, $11,1460$.

(16) Milazzo, G.; Caroli, S. "Tables of Standard Electrode Potentials"; Wiley: New York, 1978.

(17) Endicott, J. F.; Taube, H. J. Am. Chem. Soc. 1962, 84, 4984

2160 .

(19) Shepherd, R. E.; Taube, H. Inorg. Chem. 1973, 12, 1392.

(20) Vogler, A.; Losse, W.; Kunkely, H. J. Chem. Soc., Chem. Commun. 1979,187 . 
Acknowledgment. Financial support for this research by the Deutsche Forschungsgemeinschaft and the Fonds der Chemischen Industrie is gratefully acknowledged. We thank a referee for valuable comments.

Registry No. $\left[\mathrm{Ru}\left(\mathrm{NH}_{3}\right)_{9} \mathrm{Cl}\right] \mathrm{Cl}_{2}, 18532-87-1 ; \mathrm{K}_{4}\left[\mathrm{Ru}(\mathrm{CN})_{6}\right]$, 15002$31-0 ; \mathrm{Na}\left[\left(\mathrm{NH}_{3}\right)_{5} \mathrm{Ru}(\mathrm{NC}) \mathrm{Ru}(\mathrm{CN})_{5}\right], 81177-85-7$.

\section{Bimetallic Acyl Complexes. Use of Transition Organometallic Lewis Acids in Promoting Migratory CO Insertion}

Stephen J. LaCroce and Alan R. Cutler*

Department of Chemistry, Wesleyan University
Middletown, Connecticut 06457 Received October 13, 1981

Migratory $\mathrm{CO}$ insertion, which generates a metal acyl system via formal $\mathrm{CO}$ insertion into the metal-alkyl bond, serves as a fundamental reaction of organometallic chemistry ${ }^{1}$ and functions as a key step in several homogeneous catalytic transformations. ${ }^{2}$ Lewis acids moreover promote $\mathrm{CO}$ insertion ${ }^{3,4}$ to produce metal acyl-Lewis acid adducts. We now report that cationic coordinatively unsaturated $\mathrm{Cp}$ metal carbonyl complexes $\left(\mathrm{Cp}=\eta^{5}-\mathrm{C}_{5} \mathrm{H}_{5}\right)$ also induce methyl- $\mathrm{CO}$ insertion on a second metal center ${ }^{5}$ and form an acetyl ligand bridging two metal centers. Although several bimetallic complexes bearing $\mu$-acyl ligands are known, ${ }^{6}$ their syntheses entailed neither starting with a mononuclear acyl complex nor Lewis acid facilitation of the $\mathrm{CO}$ insertion step. We accordingly found it expeditious to first demonstrate that bimetallic $\mu$-[ $\left.\eta^{1}-\mathrm{C}, \mathrm{O}\right]$-acetyl compounds can be obtained from mononuclear acetyl complexes.

(1) Collman, J. P.; Hegedus, L. S. "Principles and Applications of Organotransition Metal Chemistry"; University Science Books: Mill Valley, CA,

1980; Chapter 5. Calderazzo, F. Angew. Chem., Int. Ed. Engl. 1977, 16, 299.

(2) Parshall, G. W. "Homogeneous Catalysis"; Wiley: New York, 1980; Adv. Organomet. Chem. 1979, 17. Eisenberg, R.; Hendrickson, D. E. Adv. Catal. 1979, 28, 79 .

(3) (a) Butts, S. D.; Richmond, T. G.; Shriver, D. F. Inorg. Chem. 1981, 20, 278. Butts, S. B.; Strauss, S. H.; Holt, E. M.; Stimson, R. E.; Alcock, N. W.; Shriver, D. F. J. Am. Chem. Soc. 1980, 102, 5093. (b) Berke, H.; Hoffmann, R. Ibid. 1978, 100, 7224. (c) Collman, J. P.; Finke, R.; Cawse, J. N.; Brauman, J. I. Ibid. 1978, 100, 4766. (d) Nitay, M.; Priester, W.; Rosenblum, M. Ibid. 1978, 100, 3620 .

(4) Some electrophilic reagents(e.g., $\mathrm{Ag}^{+}$) spur migratory insertion by oxidizing alkymetal carbonyl complexes. The resulting cation radical then undergoes rapid alkyl-CO migration and subsequent degradative steps: Magnuson, R. H.; Zulu, S.; Tsai, W.-M.; Giering, W. P. J. Am. Chem. Soc. 1980, 102, 6887. Johnson, M. D. Acc. Chem. Res. 1978, 11, 57 and references cited.

(5) We differentiate bimetallic reactions that incur an electron-rich metal center (i.e., a Lewis base) inducing alkyl-CO migratory insertion on a second metal center, concomitant with metal-metal bond formation: (a) Casey, C. P.; Cyre, C. R.; Anderson, R. L.; Marten, D. F. J. Am. Chem. Soc. 1975, 97, 3053. (b) Collman, J. P.; Rothrock, R. K.; Finke, R. G.; Rose-Munch, F. Ibid. 1977, 99, 7381. (c) Reference 3d.

(6) Two types of structures have been established for bimetallic structures containing $\mu$-acyl (including formyl) ligands:
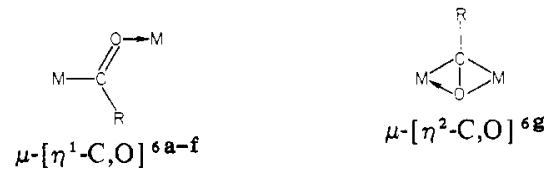

(a) Fischer, E. O.; Kiener, V.; Bunbury, D. St. P.; Frank, E.; Lindley, P. F.; Mills, O. S. Chem. Commun. 1968, 1378. Lindley, P. F.; Mills, O. S. J. Chem. Soc. A 1969, 1279. Fischer, E. O.; Kiener, V. J. Organomet. Chem. 1970, 23, 215; 1972, 42, 447. (b) Blickensderfer, J. R.; Kaesz, H. D. J. Am. Chem. Soc. 1975, 97, 2681. Blickensderfer, J. R.; Knobler, C. B.; Kaesz, H. D. Ibid. 1975, 97, 2686. (c) Merlino, S.; Montagnoli, G.; Braca, S.; Sbrana, G. Inorg. Chim. Acta 1978, 27, 233. (d) Wolczanski, P. T.; Threlkel, R. S.; Bercaw, J. E. J. Am. Chem. Soc. 1979, 101, 218. Threlkel, R. S.; Bercaw, J. E. Ibid. 1981, 103, 2650. (e) Longato, J.; Norton, J. R.; Huffman, J. C.; Marsella J. A.; Caulton, K. G. Ibid. 1981, 103, 209. (f) Lukehart, C. M. Acc. Chem Res. 1981, 14, 109. (g) Belmonte, P.; Schrock, R. R.; Churchill, M. R.; Youngs, W. J. J. Am. Chem. Soc. 1980, 102, 2858. Churchill, M. R.; Wasserman, H. J. J. Chem. Soc., Chem. Commun. 1981, 274
Neutral acetyl complexes $\mathbf{1 a}, \mathbf{b}$ and $\mathbf{2}$ coordinate the appropriate Cp metal carbonyl Lewis acid 3-5 (eq 1 and 2) by generating the
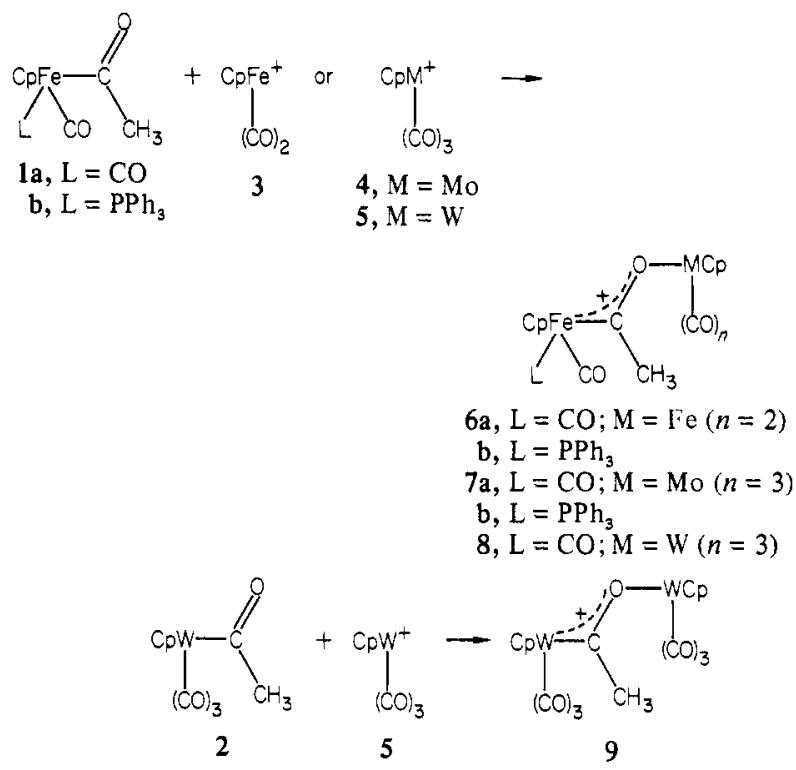

bimetallic $\mu$-acetyl adducts 6-9. Labile isobutylene ${ }^{7 a}$ or tetrahydrofuran ${ }^{7 \mathrm{~b}}$ complexes of $\mathrm{CpFe}(\mathrm{CO})_{2}{ }^{+} \mathrm{PF}_{6}{ }^{-}$(3) metalated 1a,b in refluxing $\mathrm{CH}_{2} \mathrm{Cl}_{2}(1-6 \mathrm{~h})$, whereas $\mathrm{CpM}(\mathrm{CO})_{3} \mathrm{FPF}_{5}$, a source of $\mathrm{CpM}(\mathrm{CO})_{3}{ }^{+}[4, \mathrm{M}=\mathrm{Mo} ; 5, \mathrm{M}=\mathrm{W}],{ }^{8}$ consumed $1 \mathrm{a}, \mathrm{b}$ and 2 at $\sim-20^{\circ} \mathrm{C}(0.5 \mathrm{~h})$ in $\mathrm{CH}_{2} \mathrm{Cl}_{2}$. All reactions afforded air-stable red powders 6-9 (50-85\% yields) after reprecipitating from $\mathrm{CH}_{2} \mathrm{Cl}_{2}$-ether. ${ }^{9}$ Although 6-9 remained intact in $\mathrm{CH}_{2} \mathrm{Cl}_{2}$ or $\mathrm{CH}_{3} \mathrm{NO}_{2}$ solution, acetone degraded these $\mu$-acetyl adducts to starting acetyl complexes and acetone solvates of 3-5. A similar degradative procedure serves as a convenient assay procedure for all $\mu-\left[\eta^{1}-\mathrm{C}, \mathrm{O}\right]$-acetyl complexes reported herein: 1 equiv of $(n-$ $\mathrm{Bu})_{4} \mathrm{~N}^{+} \mathrm{I}^{-}$in $\mathrm{CH}_{2} \mathrm{Cl}_{2}$ immediately and quantitatively (via IR and NMR monitoring) reverts them to the starting acetyl complex and $\mathrm{CpM}(\mathrm{CO})_{n} \mathrm{I}$.

Bimetallic $\mu$-acetyl compounds 6-9, formulated as carboxonium salts, entail $\eta^{1}$ metal-O bonding that resembles $\mathrm{CpFe}(\mathrm{CO})_{2}{ }^{+}$ complexation of organic ketones. ${ }^{10}$ The carboxonium formulation derives from the substantial delocalization of positive charge from the activating metal $\mathrm{M}$ to the $\mathrm{Fe}$ in $6-8$. IR $\left[\nu(\mathrm{C} \equiv \mathrm{O}), \mathrm{CH}_{2} \mathrm{Cl}_{2}\right]$ and ${ }^{1} \mathrm{H}$ NMR ( $\mathrm{Cp}$ in ppm, acetone- $d_{6}$ ) data of $\mathrm{CpFe}(\mathrm{CO}) \mathrm{PPh}_{3}$ in $1 \mathrm{~b}\left(1910 \mathrm{~cm}^{-1}, 4.43\right), 6 \mathrm{~b}\left(1941 \mathrm{~cm}^{-1}, 4.65\right)$, and $\mathrm{CpFe}(\mathrm{CO})-$ $\mathrm{PPh}_{3}\left[\mathrm{C}\left(\mathrm{OCH}_{3}\right) \mathrm{CH}_{3}\right]^{+} \mathrm{PF}_{6}^{-}\left(1990 \mathrm{~cm}^{-1}, 5.13\right)$ accordingly are consonant with an electronic environment of the $\mathrm{Fe}$ in $\mathbf{6 b}$ that is intermediate to the starting acetyl complex $\mathbf{1 b}$ and the methoxyethylidene salt. NMR spectra of $\mathbf{6 b}$ and $\mathbf{7 b}$ additionally support the $\eta^{1}$ bonding of the acetyl complex to an activating metal 3 or 4 , since diastereomeric mixtures were not detected for $6 \mathrm{~b}$ or 7b. ${ }^{11}$

(7) (a) Giering, W. P.; Rosenblum, M. Chem. Commun. 1971, 441. (b) Reger, D. L.; Coleman, C. J. Organomet. Chem. 1977, 131, 153.

(8) Beck, W.; Schloter, K. Z. Naturforsch., B 1978, 33B, 1214. Sünkel, K.; Ernst, H.; Beck, W. Ibid. 1981, 36B, 474.

(9) All new compounds gave satisfactory $C, H$ elemental analyses and gave IR and ${ }^{1} \mathrm{H}$ and ${ }^{13} \mathrm{C}$ NMR data in accord with the proposed structures.

(10) (a) Foxman, B.; Klemarczyk, P. T.; Liptrot, R. E.; Rosenblum, M. J. Organomet. Chem. 1980, 187, 253. (b) Schmidt, E. K. G.; Thiel, C. H. Ibid. 1981, 209, 373.

(11) This conclusion is prediced upon $\eta^{2}$ complexation of a prochiral acetyl complex creating a chiral center. Diastereomeric mixtures would then result because of the second chiral $\mathrm{Fe}$ center within the $\mathrm{CpFe}(\mathrm{CO}) \mathrm{PPh}_{3}$ group on $\mathbf{6 b}$ and $7 \mathrm{~b}$. For example, $\eta^{2}$ complexation of prochiral propene ${ }^{12 \mathrm{a}}$ or 1-butene ${ }^{12 \mathrm{~b}}$ to $\mathrm{CpFe}(\mathrm{CO}) \mathrm{PPh}_{3}{ }^{+}$gave diastereomeric mixtures that were easily discerned by NMR analysis. We also observed only a single resonance doublet $\left(\delta 1.03, J=6.0 \mathrm{~Hz}\right.$ in $\mathrm{CD}_{2} \mathrm{Cl}_{2}$ ) in the ${ }^{1} \mathrm{H}$ NMR spectrum of $\mathrm{Cp}(\mathrm{CO}), \mathrm{Fe} / \mathrm{C}$ [OMo(CO) $\left.\left.{ }_{3} \mathrm{Cp}\right] \mathrm{CH}\left(\mathrm{CH}_{3}\right)_{2}\right)^{2} \mathrm{PF}_{6}^{-}$; whereas $\eta^{2}$ coordination of the isobutyryl complex would render the gem-methyl groups diastereotopic.

(12) (a) Aris, K. R.; Brown, J. M. J. Chem. Soc., Dalton Trans. 1974, 2222. (b) Reger, D. L.; Coleman, C. J.; McElligott, P. J. J. Organomet. Chem. 1979, 177, 73 . 